\title{
Role of Integrated Nutrient Management on Nutrient Uptake, Soil Physicochemical Properties and Maize Yield Improvement: Review
}

\author{
Tolcha Tufa (MSc) \\ Ambo Agricultural Research Center, Ethiopian Institute of Agricultural Research, Addis Ababa, Ethiopia
}

\begin{abstract}
Sustainable agricultural production considers the idea that natural resources should be used to generate increased output and incomes without affecting the balance of natural resources. This can be got ahead through integrated nutrient management (INM) which embraces the use of all natural and manmade sources of plant nutrients to improve crop productivity and sustain soil productivity for future generations. Maize is a major crop that grows in a wide range of soil type that also considered as the most important cereal crops for food security in most of developing countries. It has high nutrient requirement to produce high yield with good quality. However, yield of maize is quite low in most of the region due to low soil fertility and other yield limiting factors. Currently to feed over increasing human population, agricultural intensification using high yielder or improved varieties and agrochemicals, including chemical fertilizers has an impact on ecosystem and natural environment. Intensification without proper management and the use of chemical fertilizers decreases organic matter, affect soil health and cause environmental degradation. In view of these constraints, the combined use of organic and inorganic fertilizers in improving maize crop productivity was reviewed. From reviewed literatures it was understood that the total dependence either on organic or inorganic fertilizers does not adequately enhance maize production in maize belt areas. Instead, application of integrated organic and inorganic fertilizer is more effective in increasing nutrient availability and sustain soil productivity than sole application of organic or inorganic fertilizer. Therefore, this reviewed report, recommend the combined use of organic and inorganic fertilizers to boost maize yield and replenish nutrients taken out from the soil through crop harvest and soil erosion.
\end{abstract}

Keywords: Nutrient uptake, integrated nutrient management, organic fertilizer, soil health

DOI: $10.7176 / \mathrm{JBAH} / 9-17-03$

Publication date:September $30^{\text {th }} 2019$

\section{Introduction}

Rapid increasing of human population is intensifying over utilization of natural resources and threatens the soil fertility and productivity cultivated lands (Rong et al., 2016). These problems impairs significant yield reduction per area of land which is even not sufficient for home consumption of land owners. As a result, agricultural intensification with improved varieties and agrochemicals have used to increase yield per area of the land. However, long-term application of these chemicals has a long term negative impact on ecosystem and natural environment (Salehi et al., 2017). Using of agrochemicals such as chemical fertilizers, herbicide and insecticide impairs organic matter, increases soil erosion and cause soil fertility decline at end (Singh et al., 2009). Moreover, the incidence of essential nutrients deficiencies in cultivated land has increased markedly because of intensive cropping, loss of topsoil by erosion, losses of nutrients through leaching and decreased proportions of organic matter compared to chemical fertilizer (Fageria, 2002).

Therefore, organic fertilizer with or without chemical fertilizer to compensate nutrient lost and to improve soil fertility and productivity. The application of organic amendments to manage the current soil physical, chemical and biological degradation has been recommended (Chukwu et al., 2012). However, application of only organic or inorganic fertilizer has its own merits and demerits. For instance, organic fertilizers slowly release the nutrients and the crops can suffer initial starvation from nutrient immobilization prior to mineralization. They are also required in large quantities, which may not be readily available to small scale farmers (Okigbo, 2000; Adekiya et al., 2012). On the other hand, inorganic fertilizers secure quick availability of nutrients to crops (Okigbo, 2000) and their reckless use can create nutrient imbalance that limits the uptake of other essential nutrients. In addition, they are expensive and may not be readily available to smallholder farmers.

Besides of replenishing nutrients taken out from the soil through crops harvest and other factors, using of integrated organic and inorganic fertilizers is highly needed to improve soil health of exhaustively cultivated lands (Gunjal and Chitodka, 2017). The use of both organic and inorganic fertilizer by farmers has been reported to increase yield and sustain soil productivity (Chukwu et al., 2012). Using of inorganic fertilizer along with organic materials such as cow dung, poultry manures and farm yard manure as soil amendments fruitfully improve crop production in sub-saharn Africa (Asadu and Unagwu, 2012).

Importantly, integration of organic and inorganic fertilizer is the biological amendments to increase nutrient use efficiency (NUE) and reduce nutrient loss by synchronizing crop demand (Janssen, 1993 cited in Graham et 
al., 2017). Global nutrient using efficiency (NUE) ranges from approximately $20-65 \%$ (Roberts, 2008). This can be happen due to nutrient imbalances which is common in agricultural systems where chemical fertilizer being over or under-applied. Similarly, meta-analysis of experiments in sub-Saharan Africa found that combining inorganic and organic amendments can significantly improved nutrient use efficiency (Graham et al., 2017).

Without any yield penalty, integrated nutrient management can reduce the amount of inorganic fertilizer required and significantly save scarce cash resources of smallholder farmers to be invested on chemical fertilizer. It also increase efficient use of native soil nutrients, recycling of organic nutrient flows, enhancing biological nitrogen fixation and soil biological activity (Javaria et al., 2011). Moreover, INM reduces erosion, improves water infiltration, soil aeration and minimizes the risk of downstream flooding (Salehi et al., 2017).

Maize is an important cereal crop for a large percentage of the world's population and it ranks third next to wheat and rice in the world. However, yield of maize is quite low in most of the regions due to different factors (Rachid and Ryan, 2004). Apart from these factors, low soil fertility is the major yield-limiting factor in most of the maize growing regions (Wakene et al., 2007). Maize has very high nutrient requirement and its productivity closely depends on nutrient management system. Therefore, status of soil fertility determines the level of crop productivity and low productivity of maize has mainly attributed to low fertility status of the soils (Abbasi and Khizar, 2012).

Therefore, a judicious combination of organic amendments and inorganic fertilizers is widely recommended best strategy to sustain agronomic productivity and improve soil fertility (Manna et al., 2005). As a result, this review paper focuses on the impact of INM of organic and inorganic fertilizer sources on soil environment and maize quality parameters. So that conclusion can be drawn on how far the use of integrated organic and inorganic fertilizer is helpful in sustaining soil properties, improving nutrient status of the soil and yield of maize crop.

\section{Literature Review}

\subsection{Effect Organic and Inorganic Fertilizer on Soil physical Properties}

Soil physical properties has improved by the using of organic and inorganic fertilizer together, as it reduces soil erosion and increases cycling of organic residues ( $\mathrm{Li}, 2012)$. Thus it improves both nutrient and water retention capacity of the soil due to improvement of soil structure, water infiltration, and soil aeration (Brar et al., 2015). With respect to the residual effect of organic matter on soil physical properties, several studies report soil bulk density improvement and lower penetration resistance after organic fertilizer or compost application (Hutti and fussy, 2001).

Table 1. Effect of Integrated organic and inorganic fertilizers on selected soil physical properties

\begin{tabular}{llcccccc}
\multirow{2}{*}{ N and S kg/ha } & \multicolumn{9}{c}{ Parameter } \\
\cline { 3 - 8 } & \multicolumn{3}{c}{ Bulk density } & \multicolumn{5}{c}{ Total porosity } \\
\cline { 2 - 8 } & $\mathrm{S}$ & 0 & 5 & 10 & 0 & 5 & 10 \\
\hline 0 & 0 & 1.27 & 1.24 & 0.91 & 39.9 & 49.4 & 61.8 \\
& 15 & 1.15 & 1.05 & 1.01 & 53.1 & 58.0 & 57.9 \\
& 30 & 1.11 & 1.09 & 0.88 & 56.5 & 55.5 & 63.0 \\
60 & 0 & 1.22 & 1.07 & 0.98 & 46.1 & 55.2 & 61.6 \\
& 15 & 1.16 & 0.99 & 1.0 & 50.6 & 61.2 & 59.7 \\
& 30 & 1.18 & 1.1 & 1.02 & 46.2 & 55.1 & 58.0 \\
& 0 & 1.14 & 1.05 & 0.89 & 52.3 & 55.9 & 62.1 \\
& 15 & 1.19 & 0.99 & 0.91 & 47.3 & 59.3 & 61.9 \\
& 30 & 1.25 & 1.25 & 0.93 & 50.0 & 49.6 & 62.0 \\
\hline
\end{tabular}

Source: Habtamu .2015

The study conducted at Antra Catchment, Northwestern Ethiopia was evaluated influence of integrated organic and inorganic fertilizers on selected soil physical properties. Among this soil bulk density was significantly affected by integrated organic and inorganic fertilizers (Habtamu, 2015). The lowest bulk density $(0.88) \mathrm{g} \mathrm{cm}^{-3}$ ) was recorded from soil treated with nil rate of $\mathrm{N}, 10 \mathrm{t}$ compost and $30 \mathrm{~kg} \mathrm{~S}^{-1}$ fertilizers (Table 1). Similarly, significant change in bulk density was reported in maize wheat rotation by 13 years application of NPK + manure compared to non-treated control and NPK treatment (Purakayastha et al., 2008). In contrast to this, long-term (36 years) application of inorganic fertilizers and FYM was not significantly influenced the soil bulk density (Brar et al., 2015). In line to this, application of FYM for 32 years was not brought any significant change on soil bulk density of sandy loam soil in Northern India (Kukal, 2009).

The authors also reported increment of total porosity in the soil with the application of combined effect of organic and inorganic fertilizers two years after harvesting of maize crop (Table 1). The highest total porosity $(60 \%)$ was recorded in plots treated with combined effect of $0 \mathrm{~N}, 10 \mathrm{t}$ compost ha ${ }^{-1}$ and $30 \mathrm{~kg} \mathrm{~S}^{-1}$ fertilizers. This resulted in improvement of soil porosity by $38.1 \%$ over soil collected from plot was no received any fertilizer. On the other hand, highly significant and very strong negative correlation was observed between total porosity 
and bulk density(Habtamu, 2015). This can be due to increase of soil pore spaces and decrease of soil bulk density with increasing of soil organic matter (SOM) content delivered from the applied organic fertilizer. In general application of organic matter improve soil structure/aggregation and decreased soil bulk density. This increases the percentage of pore spaces which can in turn improve soil water infiltration and water holding capacity of specific soil (Mbah and weremadu, 2009).

The study done for 36 years in India (Brar et al., 2015) reported the role of using organic and inorganic fertilizer in improving infiltration rate of the soil. Accordingly, the infiltration rate was highest in $100 \%$ NPK + FYM treatment and lowest in non-treated control. Cumulative infiltration rate was $24.83 \%$ higher in $100 \%$ NPK + FYM treatments compared to the unfertilized plot. Addition of FYM along with $100 \%$ NPK increased cumulative infiltration rate by $10.32 \%$ compared to application of $100 \%$ NPK alone (Fig1). According to Habtamu (2015) application of $\mathrm{P}$ increased infiltration rate by $11.04 \%$ compared to $100 \% \mathrm{~N}$. However, no significant increment was observed with addition of K along with NP (100\% NPK). Infiltration rate was increased by $10.88 \%$ when application of NPK was increased from $50 \%$ to $100 \%$ of the recommended rate. The highest infiltration rate was observed in $100 \%$ NPK + FYM treatment where more stable aggregation and higher SOM concentrations were measured.

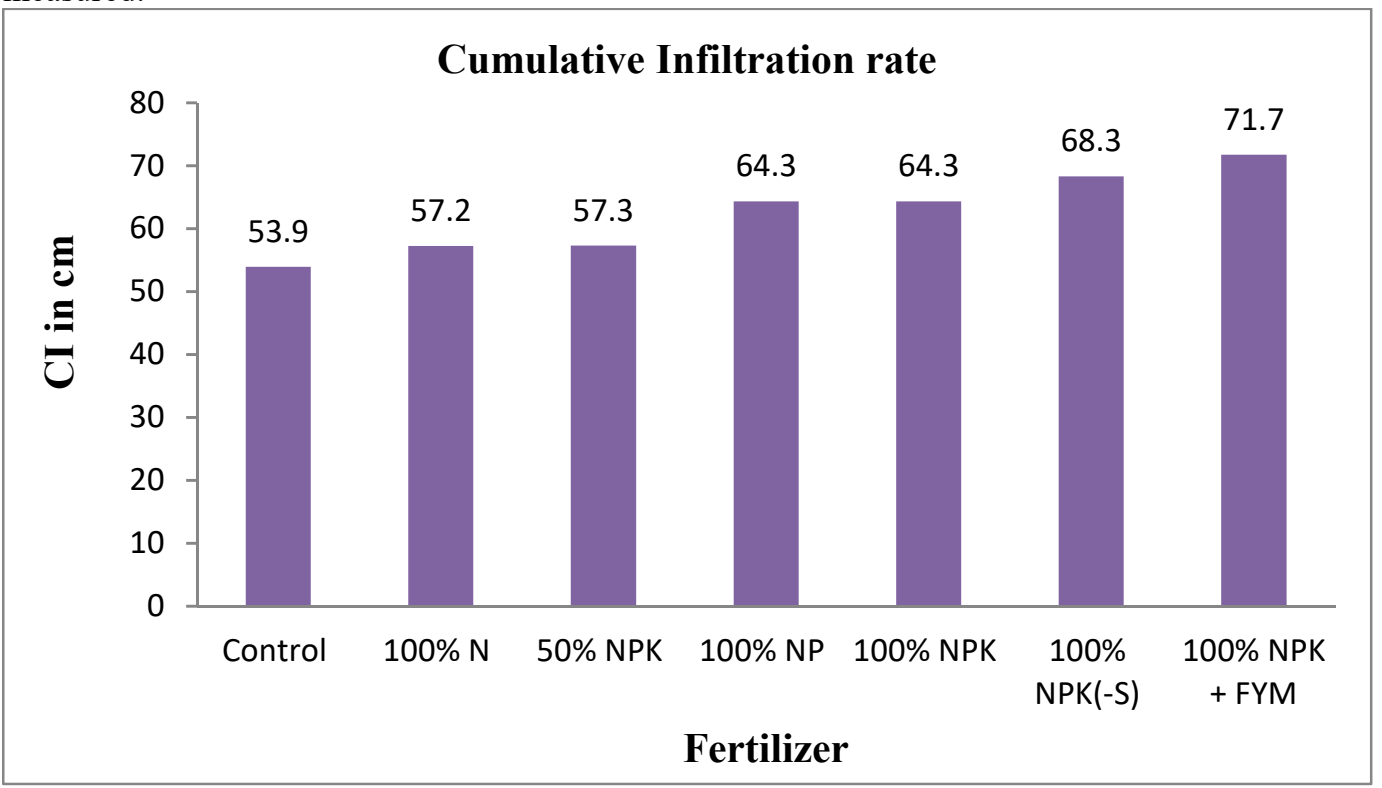

Source: Brar et al.2015

Figure 1. Effect of long-term use of organic and inorganic fertilizers on cumulative infiltration rate

The five years study conducted in Acidic Soils of Northeast India under a Maize-Mustard Cropping Sequence (Sahaa et al., 2010) was also verified importance of integrated nutrient management on soil moisture retention characteristics of the soil. According to reviewed result summarized in the above table significant impact of INM on hydraulic conductivity of the soil was also observed. Combined application of NPK, FYM, lime, and biofertilizer produced the maximum hydraulic conductivity (Table 2). It is well known that better aggregation and increased porosity as a consequence of organic fertilizer application have favorable effects on hydraulic conductivity, which is in turn influence the soil water dynamics (Sahaa et al., 2010). The hydraulic conductivity value under treatment $100 \% \mathrm{NPK}+\mathrm{L}+\mathrm{BF}+\mathrm{FYM}$ was $27.9 \%$ more than that of the control plots. Improvement in hydraulic conductivity under combined application of organic and inorganic fertilizer as compared to inorganic fertilizer alone can be due to addition of organic matter in the soil (Gunjal and Chitodka, 2017). In the same way, water-holding capacity of the soils varied from $45.25 \%$ to $54.67 \%$ under various treatments (Table 2 ). However, effect of NPK fertilizer as well as NPK + lime + microbial inoculants was not significant on water-holding capacity of the soil (Sahaa et al., 2010). Accordingly, the highest water-holding capacity $(54.67 \%)$ was also observed under continuous application of 100\% NPK and FYM, bio-fertilizer, and lime (Table 2).

Improvement in structural condition of soil due to the application of FYM with inorganic chemical fertilizer could be the possible reason for rising of water holding capacity of the soil (Aggelides et al., 2000). The soils high in organic matter has greater available water-holding capacity than the soils of similar texture with less organic matter (Hudson, 1994, Cited in Sahaa et al., 2010). Like WHC infiltration capacity of the soil was observed due to combined applications of organic manures and inorganic fertilizers. Similarly, Sarkar and Singh (2003) also found better moisture-retention capacity and infiltration rate of the surface soil after application of organic fertilizer for nine cropping season. 
Table 2. Effect of integrated use of organic, inorganic, and biological nutrient sources on some soil Physical properties

\begin{tabular}{llll}
\hline Treatments & $\mathrm{HC}(\mathrm{m} / \mathrm{s} \times 10-6)$ & WHC $(\%)$ & IR $(\mathrm{ms}-1 \times 10-6)$ \\
\hline Control & 3.92 & 45.25 & 2.11 \\
$50 \%$ NPK & 4.11 & 46.31 & 2.20 \\
$100 \%$ NPK; & 4.22 & 44.50 & 2.19 \\
$50 \%$ NPK+L+BF & 4.17 & 45.05 & 2.65 \\
$100 \%$ NPK+L+BF & 4.53 & 46.86 & 2.88 \\
$50 \%$ NPK + L+ FYM & 4.14 & 48.12 & 3.16 \\
$100 \%$ NPK+ L + FYM & 4.39 & 49.26 & 3.33 \\
$50 \%$ NPK + FYM + BF & 4.31 & 48.64 & 3.54 \\
$100 \%$ NPK + FYM + BF & 4.56 & 49.38 & 3.76 \\
$50 \%$ NPK + L + BF FYM & 5.19 & 52.15 & 3.95 \\
$100 \%$ NPK + L + BF +FYM & 5.44 & 54.67 & 4.08 \\
\hline CD $($ P = 0.05) & 0.02 & 1.82 & 0.03 \\
\hline
\end{tabular}

Source :( Sahaa et al.2010)

Note: BF-Biofertilizer, L (Lime), HC (Hydraulic Conductivity), WHC, (Water Holding Capacity), Infiltration rate (IR)

\subsection{Effect of Organic and Inorganic Fertilizer on Soil Chemical Properties}

Application of organic fertilizer alone as well as combined application of organic and inorganic fertilizer improve soil chemical properties. Organic fertilizers are main source of soil organic matter, percentage of organic carbon and total nitrogen which are play a vital role in improvement of other soil properties (Javaria, 2011). Organic fertilizer recover total organic carbon (TOC) levels in the soil while chemical fertilizer reduce TOC, basic cation contents and lowering soil $\mathrm{pH}$. A number of studies confirmed this fact through application of organic and inorganic fertilizer. For Instance, Brar et al. (2015) studied effects of long-term application of inorganic and organic Fertilizers on soil Electrical conductivity (EC), $\mathrm{pH}$ and Cation exchange capacity (CEC) in maize-wheat rotation and their result was summarized in the following table. Compared to other fertilizer treatments except unfertilized soil, application of FYM and combination of FYM with inorganic Fertilizer was not significantly influenced soil $\mathrm{pH}$. However, the presence of significant effect on soil acidity and phosphorus availability was reported elsewhere by Opala et al. (2012). The rise in soil $\mathrm{pH}$ could have been due the exchange of the proton $\left(\mathrm{H}^{+}\right)$ between the soil and organic anions. This organic anions (phenolic and humic acids) consume the proton and increase the soil pH (Haynes and Mokolobate, 2001).

Similarly, application of composted pig manure (CPM) with chemical fertilizer for twenty-one years on Chinese Mollisols had a significant effect on soil chemical and biological properties (Li, 2012). This study indicated that the chemical $\mathrm{N}$ fertilizer reduced the soil $\mathrm{pH}$ from 6.20 to 5.7 while, application of CPM could relieve the negative impact of $\mathrm{N}$ application on $\mathrm{pH}$ and NPK + CPM application maintained the soil $\mathrm{pH}$ at the initial level. In line to this Hati et al. (2006) also reported important of cattle manure or NPK plus manure application over application of chemical fertilizer alone to maintain soil $\mathrm{pH}$. Long term application of inorganic fertilizer and farm yard manure was not significantly influenced the soil electro conductivity (Table 3). According to EC critical range set by FAO (2008) all EC values ( 0.17-0.8 $\left.\mathrm{dS} \mathrm{m}^{-1}\right)$ recorded from residual effect of applied fertilizers were salt free or safe for growth of all crops. In contrast, Hati et al., (2006) reported improvement of soil EC with long-term application of $100 \%$ NPK + FYM compared to non-treated control and other inorganic fertilizer in soybean-wheat-maize rotation. The lowest CEC value was found in soil received nothing and $100 \%$ Nitrogen (Table 3). The authors also find highest CEC in 150\% NPK + FYM treatment. The CEC of $150 \%$ NPK + FYM treatment was $14 \%$ higher compared to $100 \%$ NPK + FYM.

Table 3. Physical and chemical characteristics of the soil among different fertilizer treatments

\begin{tabular}{lcccc}
\hline Treatment & $\mathrm{pH}(1: 2)$ & $\mathrm{EC}(\mathrm{dS} / \mathrm{m})$ & Bulk Density $(\mathrm{Mg} / \mathrm{m} 3)$ & CEC $(\mathrm{C} \mathrm{molc} / \mathrm{kg})$ \\
\hline $50 \% \mathrm{NPK}$ & $7.49^{\mathrm{b}}$ & $0.21^{\mathrm{a}}$ & $1.57^{\mathrm{a}}$ & $5.7^{\mathrm{bc}}$ \\
$100 \% \mathrm{NPK}+\mathrm{W}$ & $7.39^{\mathrm{bc}}$ & $0.20^{\mathrm{a}}$ & $1.56^{\mathrm{a}}$ & $5.8^{\mathrm{bc}}$ \\
$150 \% \mathrm{NPK}+\mathrm{FYM}$ & $7.25^{\mathrm{c}}$ & $0.20^{\mathrm{a}}$ & $1.56^{\mathrm{a}}$ & $6.7^{\mathrm{a}}$ \\
$100 \% \mathrm{NPK}$ & $7.39^{\mathrm{bc}}$ & $0.19^{\mathrm{a}}$ & $1.53^{\mathrm{a}}$ & $5.8^{\mathrm{bc}}$ \\
$100 \% \mathrm{NPK}+\mathrm{Zn}$ & $7.38^{\mathrm{bc}}$ & $0.21^{\mathrm{a}}$ & $1.56^{\mathrm{a}}$ & $5.9^{\mathrm{bc}}$ \\
$100 \% \mathrm{NP}$ & $7.30^{\mathrm{bc}}$ & $0.18^{\mathrm{a}}$ & $1.53^{\mathrm{a}}$ & $5.8^{\mathrm{bc}}$ \\
$100 \% \mathrm{~N}$ & $7.40^{\mathrm{bc}}$ & $0.20^{\mathrm{a}}$ & $1.54^{\mathrm{a}}$ & $5.2^{\mathrm{c}}$ \\
$100 \% \mathrm{NPK}+\mathrm{FYM}$ & $7.37^{\mathrm{b}}$ & $0.20^{\mathrm{a}}$ & $1.49^{\mathrm{a}}$ & $5.9^{\mathrm{bc}}$ \\
$100 \% \mathrm{NPK}(-\mathrm{S})$ & $7.38^{\mathrm{b}}$ & $0.17^{\mathrm{a}}$ & $1.55^{\mathrm{a}}$ & $6.4^{\mathrm{b}}$ \\
Control & $7.90^{\mathrm{a}}$ & $0.20^{\mathrm{a}}$ & $1.59^{\mathrm{a}}$ & $5.2^{\mathrm{c}}$ \\
\hline
\end{tabular}

Source: Brar et al.2015 


\subsection{Role of Organic and Inorganic Fertilizer on Maize Production}

Different results reported that integrated nutrient management practices significantly improved macro and micronutrient status of soils in maize cropping system. The activity of soil organisms is very important for guaranteeing sufficient nutrient supply to plant.

Table 4: Effect of NP and FYM on grain yield of hybrid maize (BH-140) at Chiro, western Hararghe from 2008to 2011.

\begin{tabular}{|c|c|}
\hline Treatment & Grain yield kg/ha \\
\hline Control (0 FYM and 0 urea and DAP) & $1647.5^{\mathrm{e}}$ \\
\hline $10 \mathrm{t} / \mathrm{ha} \mathrm{FYM}+0 \mathrm{~N}$ and $\mathrm{P}$ & $6653^{\mathrm{b}}$ \\
\hline $8 \mathrm{t} / \mathrm{ha} \mathrm{FYM}$ and $25 \mathrm{~kg} / \mathrm{ha}$ urea $+20 \mathrm{~kg} / \mathrm{ha}$ DAP & $5857^{\mathrm{c}}$ \\
\hline $6 \mathrm{t} / \mathrm{ha} \mathrm{FYM}$ and $50 \mathrm{~kg} / \mathrm{ha}$ Urea $+40 \mathrm{~kg} / \mathrm{ha}$ DAP & $5171^{\mathrm{d}}$ \\
\hline 4 t/ha FYM and $75 \mathrm{~kg} / \mathrm{ha}$ Urea $+60 \mathrm{~kg} / \mathrm{ha}$ DAP & $8159^{a}$ \\
\hline 2 t/ha FYM and $100 \mathrm{~kg} / \mathrm{ha}$ Urea $+80 \mathrm{~kg} / \mathrm{ha}$ DAP & $6669^{b}$ \\
\hline $100 \mathrm{~kg} / \mathrm{ha}$ Urea $+100 \mathrm{~kg} / \mathrm{ha}$ DAP & $6997^{\mathrm{b}}$ \\
\hline LSD 5\% & 553.3 \\
\hline $\mathrm{CV}(\%)$ & 6.3 \\
\hline
\end{tabular}

Source: Zelalem .2013

In suitable conditions microorganisms can be very efficient in dissolving nutrients and making them available to plants (Javaria, 2011). Balanced application of inorganic and organic fertilizers improved the soil fertility status in addition to increase in maize yield (Ali et al., 2012). A number of studies were found a sustainable and significantly improved yield and yield related parameters of maize due to long term application of integrated organic and inorganic fertilizers. For instance Zelalem, 2013 reported statistically significant effect of integrated nutrient management on maize grain yield. In finding the maximum grain yield $\left(8159 \mathrm{~kg} \mathrm{ha}^{-1}\right)$ was obtained from field treated with $4 \mathrm{tha}^{-1}$ FYM and $75 \mathrm{~kg} \mathrm{ha}^{-1}$ Urea $+60 \mathrm{~kg} \mathrm{ha}^{-1}$ DAP fertilizer (Table 4).

Similarly, study in Islamabad revealed that substitution of 25 or $50 \% \mathrm{~N}$ by FYM $+4 \mathrm{Zn} \mathrm{kg} \mathrm{ha}^{-1}$ provided better grain and straw yield than $100 \%$ recommended $\mathrm{N}$ from chemical fertilizer alone. Maximum maize grain yield $\left(5.18 \mathrm{t} \mathrm{ha}^{-1}\right)$ was obtained with $75 \%$ chemical fertilizer (CF) $+25 \%$ Farm Yard Manure (FYM) (Sarwar, 2012). In general, the result of this and other findings indicated that all proportions of FYM and inorganic fertilizer treatments significantly increased maize grain yield as compared to the control treatment. Moreover, 20 years experimental study at Kathalagere, India, provided higher maize grain yield with application of FYM and $50 \%$ NPK inorganic fertilizers (Sathish, 2011).

Table 5. Effect of INM on yield and yield components of maize crop

\begin{tabular}{|c|c|c|c|}
\hline Treatments & $\begin{array}{l}1000 \text { seed } \\
\text { weight }(\mathrm{g})\end{array}$ & $\begin{array}{c}\text { Grain } \\
\text { Yield } \mathrm{Kg} / \mathrm{ha}\end{array}$ & $\begin{array}{l}\text { Biological } \\
\text { yield } \mathrm{kg} / \mathrm{ha}\end{array}$ \\
\hline Control (unfertilized) & $232.91^{\mathrm{d}}$ & $2489^{f}$ & $11050^{c}$ \\
\hline Nitrogen alone $(150 \mathrm{~kg} / \mathrm{ha})$ & $245.47^{\text {bcd }}$ & $3742^{\text {ce }}$ & $13646^{\mathrm{b}}$ \\
\hline FYM Alone $(12 \mathrm{t} / \mathrm{ha})$ & $234.71^{\mathrm{cd}}$ & $2800^{\text {ef }}$ & $10735^{c}$ \\
\hline PM Alone $(5 \mathrm{t} / \mathrm{ha})$ & $235.43^{\mathrm{cd}}$ & $2664 c^{\mathrm{ef}}$ & $9688^{c}$ \\
\hline $25 \% \mathrm{~N}+75 \% \mathrm{FYM}$ & $241.95^{\mathrm{cd}}$ & $3140^{\mathrm{d}}$ & $10953^{c}$ \\
\hline $50 \% \mathrm{~N}+50 \% \mathrm{FYM}$ & $248.61^{\mathrm{abc}}$ & $4178^{a b}$ & $16139^{a}$ \\
\hline $75 \% \mathrm{~N}+25 \% \mathrm{FYM}$ & $256.70^{\mathrm{abc}}$ & $3866^{\mathrm{c}}$ & $13147^{b}$ \\
\hline $25 \% \mathrm{~N}+75 \% \mathrm{PM}$ & $248.31^{\mathrm{abc}}$ & $2611^{\mathrm{ef}}$ & $9572^{c}$ \\
\hline $50 \% \mathrm{~N}+50 \% \mathrm{PM}$ & $262.62^{\mathrm{a}}$ & $4306^{\mathrm{a}}$ & $16502^{a}$ \\
\hline $75 \% \mathrm{~N}+25 \% \mathrm{PM}$ & $258.90^{\mathrm{ab}}$ & $3960^{\mathrm{ab}}$ & $13900^{\mathrm{b}}$ \\
\hline
\end{tabular}

\section{Note: FYM= Farm Yard Manure, $\mathbf{P M}=$ Poultry Manure}

Source: Ali et al. (2012)

According to field trial of Ali et al. (2012) application of poultry and farm yard manure along with nitrogen from inorganic fertilizer resulted in higher yield and yield components of maize compared to application of organic or mineral nitrogen alone (Table 5). In this study, combination of $50 \%$ poultry manure (PM) $+50 \% \mathrm{~N}$ from chemical fertilizer and 50\% FYM $+50 \% \mathrm{~N}$ from chemical fertilizer improved maize yield by $73 \%$ and $67.86 \%$ respectively over unfertilized one. Similarly, Cheema, et al. (2010) reported that applying 50\% N from poultry manure and $50 \% \mathrm{~N}$ from urea fertilizer produced maximum grain yield of maize (5.6 t ha-1), harvest index (24.91\%) and grain weight per cob (68.98 g) compared to unfertilized treatment which gave the lowest harvest index (15.71\%), grain yield (2.40 tha-1) and weight per cob $(44.53 \mathrm{~g})$.

2.4 Role of Organic and Inorganic Fertilizer on Nutrient Uptake

The integrated use of organic and inorganic fertilizers boost further the maize grain yield and improve soil chemical 
properties. The results of Wakene et al. (2007) showed that the uptake of $\mathrm{N}$ and $\mathrm{P}$ was significantly enhanced in improved Fallow supplemented with low dose of NP fertilizers and FYM. The authors reported significantly low uptake of K when recommended NP was applied from chemical fertilizer compared to the integrated one (Table 6). The finding were in line with similar studies conducted elsewhere. For instance, study conducted in Uganda, showed that sorghum yield was significantly improved in improved fallow and FYM over the control treatment (Kiazzi et al., 2006). The authors generally declared that improved fallow along with FYM or low dose of NP fertilizers conserves nutrients in the soil and makes nutrient uptake more efficient. Furthermore, integrated use of mineral $\mathrm{N}$ from urea and organic $\mathrm{N}$ from farmyard manure provided better nitrogen concentration, nitrogen uptake and yield of maize than unfertilized treatment (Mahmooda et al.,2014). In this case application of 150 or $200 \mathrm{~kg} \mathrm{~N} \mathrm{ha}^{-1}$ and $10 \mathrm{t} \mathrm{FYM} \mathrm{ha}^{-1}$ was found best for obtaining higher $\mathrm{N}$ uptake of maize and dry matter yield of maize. Brar et al. (2015) also conducted a long term field experiment for 36 years from 1971 to 2007 at Punjab Agricultural University (PAU) in India.

Table 6: Effect of integrated nutrient management on uptake of $\mathrm{N}, \mathrm{P}$, and $\mathrm{K}$ of maize

\begin{tabular}{lccc}
\hline Treatment & $\mathrm{N}(\%)$ & $\mathrm{P}(\mathrm{ppm})$ & $\mathrm{K}(\mathrm{mg} / \mathrm{kg})$ \\
\hline Control (unfertilized) & $0.48^{\mathrm{b}}$ & $0.16 \mathrm{c}$ & $1.71^{\mathrm{a}}$ \\
Improved farrow (IF) & $1.92^{\mathrm{a}}$ & $0.19^{\mathrm{b}}$ & $1.59^{\mathrm{ab}}$ \\
$\mathrm{IF}+55 / 10 \mathrm{~kg} \mathrm{ha}^{-1} \mathrm{~N} / \mathrm{P}$ & $1.90^{\mathrm{a}}$ & $0.18^{\mathrm{b}}$ & $1.61^{\mathrm{ab}}$ \\
$\mathrm{IF}+37 / 7 \mathrm{~kg} \mathrm{ha}^{-1} \mathrm{~N} / \mathrm{P}$ & $1.88^{\mathrm{a}}$ & $0.18^{\mathrm{b}}$ & $1.71^{\mathrm{a}}$ \\
$\mathrm{IF}+4 \mathrm{t} \mathrm{ha}^{-1} \mathrm{FYM}^{\mathrm{b}}$ & $2.12^{\mathrm{a}}$ & $0.22^{\mathrm{a}}$ & $1.75^{\mathrm{a}}$ \\
$\mathrm{IF}+2.7 \mathrm{t} \mathrm{ha}^{-1} \mathrm{FYM}$ & $2.15^{\mathrm{a}}$ & $0.22^{\mathrm{a}}$ & $1.75^{\mathrm{a}}$ \\
$110 / 20 \mathrm{~kg} \mathrm{ha}^{-1} \mathrm{~N} / \mathrm{P}$ & $2.07^{\mathrm{a}}$ & $0.17^{\mathrm{bc}}$ & $1.42^{\mathrm{b}}$ \\
\hline LSD $(5 \%)$ & 0.33 & 0.02 & 0.21 \\
CV $(\%)$ & 9.66 & 11.27 & 7.09 \\
\hline
\end{tabular}

Source: Wakene et al. 2017

The results showed that the nutrient uptake for $\mathrm{N}, \mathrm{P}$ and $\mathrm{K}$ was significantly higher in all fertilizer treatments compared to non-treated control (Figure 2). The N and P uptake significantly increased as application rate of NPK increase from $50 \%$ to $150 \%$. According to research result of these authors $\mathrm{N}$ and $\mathrm{P}$ uptake was highest with application of $100 \%$ NPK + FYM. But K uptake was higher in 150\% NPK which was not significantly different from K uptake in $100 \%$ NPK + FYM, $100 \%$ NPK and 100\% NPK + W. This finding was in line with that of Chukwu et al., (2012) who worked on integrated effect of poultry and NPK fertilizer on soil properties and nutrient uptake compared to application of mineral fertilizer alone.

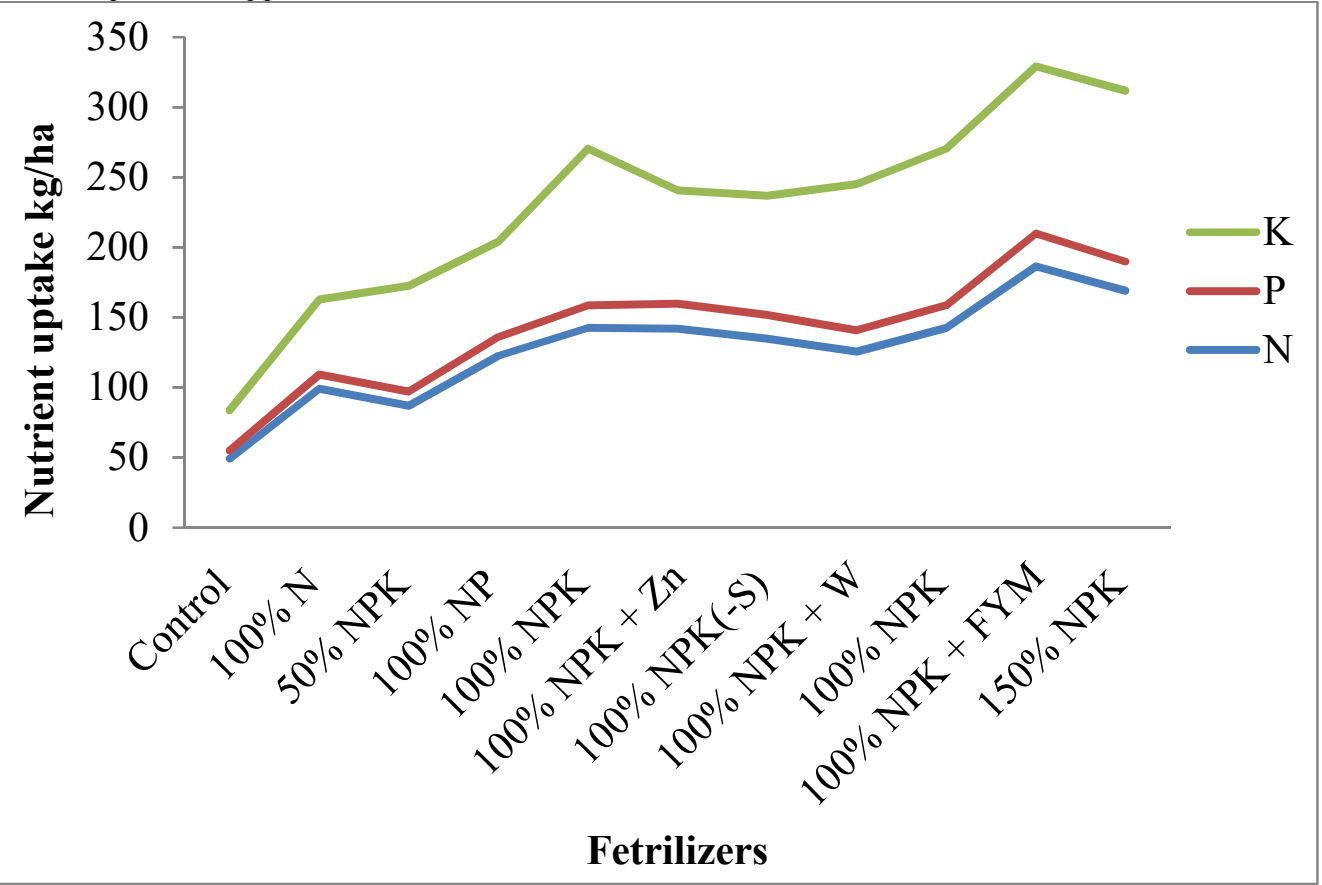

Figure 2. Effect of Organic and Inorganic fertilizer on nutrient uptake (Brar et al., 2015)

Similarly, soil available $\mathrm{P}$, exchangeable $\mathrm{K}, \mathrm{Ca}$ and $\mathrm{Mg}$ as well as effective cation exchange capacity (ECEC) were significantly improved by the combined application of organic and inorganic fertilizers (Chukwu et al., 2012). 


\section{Conclusions}

Application of integrated organic and inorganic fertilizer is more effective in increasing nutrient availability and maize yield than sole application of either organic or inorganic fertilizer. This practice can protect soil health and improve soil fertility for sustainable crop production. In general, integrated nutrient management improves the soil organic matter and nutrient availability as well as soil microbial activities in the soil. It is normally, believed that the combination of organic and inorganic fertilizer will increase synchrony, enhancing the efficiency of applied chemical fertilizers and reduces nutrient losses by conserving nutrients in the soil. Integrated nutrient management also reduces environmental problems that may arise from inappropriate use of inorganic fertilizer. However, this technology is not yet widely adopted by farmers. This can be due to different problems such as luck of organic inputs, use of organic resources for other purposes, luck of transport access and awareness on this technology. Based on this review it can be concluded that the use of integrated application of organic and inorganic fertilizers is a milestone for sustainable agriculture as well as enhancement of farmers' potential for maize production. As a result, it is the best recommendation for developing countries where soil fertility management system such as crop rotation, crop residue management and fallowing are rare due to increase of human population and shortage of cultivated land.

\section{References}

Abbasi, M. K. and Khizar, A.: Microbial biomass carbon and nitrogen transformations in a loam soil amended with organic inorganic $\mathrm{N}$ sources and their effect on growth and N-uptake in maize. Ecological Engineering, 39, 23-132, 2012.

Adekiya, A.O., Ojeniyi, S.O. and Agbede, M.T. 2012. Poultry manure effects on soil properties, leaf nutrient status, growth and yield of cocoyam in a tropical Alfisol. Nigerian Journal of Soil Science, 22(2):30 - 39.

Aggelides, S. M., and P. A. Londra. 2000. Effect of compost produced from town wastes and sewage sludge on the physical properties. Bio-resource Technology, 71(1):253-259.

Ali, K., and Khalil S. K., 2012. Munsif, F. Abdur, R., K. Nawab, K. Khan, A. Z., Kamal A, and Khan, H. Z. Response of maize to various nitrogen sources and tillage practices. Sarhad Journal of Agriculture, 28(1): 914.

Brar, B. S. Jagdeep Singh, Gurbir Singh and Gurpreet Kaur. 2015. Effects of Long Term Application of Inorganic and Organic Fertilizers on Soil Organic Carbon and Physical Properties in Maize-Wheat Rotation. Agronomy, 5: $220-238$.

Cheema, M. A., Farhad.W, Saleem. M. F., Khan. H. Z., Munir. A., Wahid .M. A., Rasul. F. and Hammad. H. M. 2010. Nitrogen management strategies for sustainable maize production. Crop and Environment, 1(1): 49-52.

Chukwu, L.I., Ano, A.O. and Asawalam, D.O. 2012. Effects of Poultry Manure and NPK fertilizer on soil properties and Nutrient uptake of maize (Zea mays L.) plants growth in an ultisol.In: Proceedings of the 36th Annual Conference of the Soil Science Society of Nigeria on 7 - 11 March 2012. University of Nigeria, Nsukka.

Fageria, N.K. 2002. Nutrient management for sustainable dry bean production in the tropics. Communications in Soil Science and Plant Analysis, 33: 1537-1575.

FAO (Food and Agricultural Organization of the United Nations). 2008. Guide to laboratory establishment for plant nutrient analysis: Fertilizer and Plant Nutrition Bulletin 19. Food and Agriculture Organization of the United Nations, Rome, Italy.

Graham, R.F, Wortman, S.E and Pittelkow, C.M .2017.Comparison of Organic and Integrated Nutrient Management Strategies for Reducing Soil $\mathrm{N}_{2} \mathrm{O}$ Emissions. Department of Agronomy and Horticulture, University of Nebraska, Lincoln, USA.

Gunjal, B.S. and Chitodka, S.S. 2017. Effect of integrated nutrient management on soil properties and soil fertility under in sweet cornpotato cropping sequence in vertisols of Deccan plateau of India. International Journal of Chemical Studies, 5(6): 1343-1351.

Habtamu Admas. 2.015. Effects of Organic and Inorganic Fertilizers on Selected Soil Properties after Harvesting Maize at Antra Catchment, Northwestern Ethiopia. International Invention Journal of Agricultural and Soil Science, 3(5): 68-78.

Hati, K.M., Swarup, A., Singh, D., Misra, A.K., Ghosh, P.K. 2006. Long-term continuous cropping, fertilization, and manuring effects on physical properties and organic carbon content of a sandy loam soil. Aust. J. Soil Res. 44, 487-495.

Haynes R.J. and Mokolobate, M.S. 2001. Amelioration of Al toxicity and P deficiency in acid soils by additions of organic residues: a critical review of the phenomenon and the mechanisms involved. Nutrient Cycling in Agroecosystems, 59: 47-63.

Hutti, F. R and Fussy, M.2001. Organic Matter Management -A Contribution to Sustainability. pp. 9-17.In: Stefan P. (ed.), Seminar proceeding of applying compost benefits and need, 22 - 23 November .2001. Brussels, Belgium. 
Javaria, Sadaf and Khan, M. Qasim. 2011. Impact of Integrated Nutrient Management on Tomato Yield Quality and Soil Environment. Journal of Plant Nutrition, 34(1): 140-149.

Kaizzi, K.C, J. Byalebeka, C. S. Wortmann, and M. Mamo. 2006. Low input approaches for soil fertility management in semiarid eastern Uganda. Agronomy Journal, 99:847-853.

Kukal, S., Rehanarasool, S. and Benbi, D.K. 2009. Soil organic carbon sequestration in relation to organic and inorganic fertilization in rice-wheat and maize-wheat systems. Soil Tillage Research, 102(1): 87-92.

Li, X. H., Han, X. Z., Li, H. B., Song, C., Yan, J. and Liang, Y. 2012.Soil chemical and biological properties affected by 21-year application of composted manure with chemical fertilizers in a Chinese Mollisol. Canadian Journal of Soil Science, 92(3):419-428).

Mahmooda Buriro, Avinash Oad, Tahmina Nangraj, Allah Wadhayo Gandahi .2014. Maize Fodder Yield and Nitrogen Uptake as Influenced by Farm Yard Manure and Nitrogen Rates. European Academic Research. 2(9):11624- 11637.

Manna, M., Swarup, A.; Wanjari, R., Ravankar, H., Mishra, B., Saha, M., Singh, Y., Sahi, D., Sarap, P.2005. Long-term effect of fertilizer and manure application on soil organic carbon storage, soil quality and yield sustainability under sub-humid and semi-arid tropical India. Field Crop Research. 93(2-3): 264-280.

Mbah C.N, Onweremadu E.U .2009. Effect of Organic and Mineral Fertilizer Inputs on Soil and Maize Grain Yield in an Acid Ultisol in Abakaliki-South Eastern Nigeria. American-Eurasian Journal of Agronomy, 2(1): 7 - 12 .

Okigbo, I .2000. Application of organic and inorganic fertilizers and the response of maize crop. Nigerian Journal of Soil Science.18 (2). 22.

Opala, P.A., Okalebo, J.R. and Othieno, C.O. 2012. Effect of organic and inorganic materials on soil acidity and phosphorus availability in a soil incubation study. International Scholarly Research Agronomy, 2012:1-10.

Purakayastha, T.J., Rudrappa, L., Singh, D., Swarup, A.; Bhadraray, S. 2008. Long-term impact of fertilizers on soil organic carbon pools and sequestration rates in maize-wheat-cowpea cropping system. Geoderma, 144:370-378

Rachid, R. and Ryan, I. 2004. Response of maize crop to different levels of organic and inorganic fertilizers application. Nigerian journal of Soil Science. 18 (2): 55.

Roberts, T.L. 2008. Improving nutrient use efficiency. Turkey Journal of Agriculture, 32:177-182.

Rong, Yang R., Zhong, Y., Tao W. and Qin Y. 2016. Effect of chemical and organic fertilization on soil carbon and nitrogen accumulation in a newly cultivated farmland. Journal of Integrative Agriculture, 15(3): 658-666.

Salehi A., Fallah S. and Sourki, A. 2017. Organic and inorganic fertilizer effect on soil $\mathrm{CO}_{2}$ fux, microbial biomass, and growth of Nigella sativa L. International Agrophysics, 31:103-116.

Sarkar, S. and Singh, S.R 2003 .The effect of organic and inorganic fertilizers on soil physical condition and the productivity of a rice-lentil cropping sequence in India. The Journal of Agricultural Science, 140(4): 419425.

Sarwar, M. J. Ghulam, R. Ejaz, A. Muhammad Ehsan, and C. Arshad Nawaz. 2012. Impact of integrated nutrient management on yield and nutrient uptake by maize under rain fed conditions. Pakistan Journal of Nutrition, 11: $27-33$

Sathish A., Govinda V., Gowda, H. Chandrappa and Nagaraja K. Long term effect of integrated use of organic and inorganic fertilizers on productivity, soil fertility and uptake of nutrients in rice and maize cropping system. International International Journal of Science and Nature, 2:84-88.

Singh, A.K, Sarkar, A.K., Kumar, A. and Singh, B.P.2009. Effect of long term use of mineral fertilizer, lime and farmyard manure on the crop yield, available plant nutrient and heavy metal status in acidic loam soil. Journal of the Indian Society of Soil Science, 57: 362-365.

Wakene Negassa, Fite Getaneh, Abdena Deressa, and Berhanu Dins. 2007. Integrated Use of Organic and Inorganic Fertilizers for Maize Production. In: Utilization of diversity in land use systems: Sustainable and organic approaches to meet human needs. 9 - 11 October 2007. Tropentag, Witzenhausen, Germany.

Zelalem Bekeko.2013.Improving and sustaining soil fertility by use of enriched farmyard manure and inorganic fertilizers for hybrid maize (BH-140) production at West Hararghe zone, Oromia, Eastern Ethiopia. African Journal of Agricultural, 8(14):1218-1224. 